\title{
STAREA ACTUALĂ A CODALBULUI (HALIAETUS ALBICI- LLA) DE PE TERITORIUL REPUBLICII MOLDOVA
}

\author{
Crudu Vasile \\ Institutul de Zoologie, Chișinău, R. Moldova; acipiter90@gmail.com \\ https://doi.org/10.53937/9789975315975.08
}

Codalbul (Haliaeetus albicilla) este o pasăre răpitoare de zi, protejată, din ordinul falconiformelor (Falconiformes), familia Accipitridae. În Republica Moldova Codalbul este inclusă în Cartea Roșie cu statutul CR, fiind răspândită doar în regiunea rîului Prut și fluviului Nistru. Este o pasăre de talie mare (80-100 cm, cu corpul cafeniu, coada albă, ciocul galben puternic, lung, drept, încovoiat spre vârf și picioare galbene, la fel ca și degetele; unghii negre, mult curbate. Se hrănește cu pești, broaște, șerpi, rațe, iepuri, popândăi, hoituri. Cuibărește în arbori din vecinătatea apelor. Specia este răspândită predominant în Norvegia și Rusia (mai ales în Siberia), care dețin împreună > 55\% din populația europeană, populații importante se află în sud-vestul Groenlandei, Danemarca, Suedia, Polonia și Germania. Un număr mic de exemplare se găsesc în Islanda, Finlanda, Estonia, Letonia, Belarus, Austria,, Bulgaria, România, Republica Moldova, Ungaria s.a. La nivelul mondial se estimează că există 50007000 de perechi de codalbi.

Investigațiile conform obiectivelor trasate pentru identificarea tuturor cuiburilor ocupate de Codalb de pe teritoriul Republicii Moldova sau efectuat în diferite zone, unde anterior au fost observați indivizi ocazionali. Cercetările au fost efectuate în următoarele locații: Rezervația Știinșifică „Pădurea Domnească" „Prutul de Jos", Pădurile din lunca Nistrului, și alte zone unde se încadrează habitate perfecte pentru cuibăritul aceste specii.

Începînd cu toamna anului 2012 și primăvara lui 2013 până a nu fi împânzite de vegetație aceste zone au fost verificate cu scopul identificării tuturor cuiburilor, ca mai apoi în perioada caldă a anului sa fie încă odată vizitate pentru determinarea gradului de cuibărire a acestora. 
Mai bine de 30 de ani starea populație de Codalb de pe teritoriul Republicii Moldova nu a fost studiată. In aceasta perioadă nu erau identificate locații concrete unde ar putea cuibări această specie, și erau doar descrise zone cu potențial de cubărit. După identificarea primului cuib de Codalb în primăvara anului 2012 în rezervația „Pădurea Domnească” sa insistat pe identificarea acestora și în alte locuri, prin urmare la începutul anului de cuibărit 2013 erau identificate deja 4 cuiburi ocupate de această specie, dintre care două erau în Rezervația științifică „Pădurea Domnească” și două in Rezervația științifică „, Prutul de Jos”. Încă rămâne incertă a cincea locație în care perechea de Codalbi este observată deja de 5 ani consecutivi in aceeași zona în perioada de cuibărit dar cuibul așa si nu s-a identificat. Toate cele patru locații sunt situate în nemijlocita apropiere de lacuri sau întinderi de apă, unde acesta își dobândește hrana din perioada de cuibărit. Cuiburile din zona de Nord au ca loc pentru hrană lacurile din preajma rezervației și lacul de acumulare "Costești Stânca” , pe când cele din zona de sud au tot sistemul de lacuri din cadrul rezervației „Prutul de Jos".

Trebuie de menționat că defrișările masive ce au loc în Republica Moldova duc la dispariția multor specii de păsări. Astfel în 2015 în Rezervația Științifică "Pădurea Domnească" a fost doborât un arbore ce era ca suport pentru un cuib de codalb.

De obicei speciile de codalbi pot alege ca suport pentru cuib mai multe specii de copaci cum ar fi: speciile de copaci din genul (Populus), (Pinus), (Fagus), (Quercus), (Salix) etc. La noi în tară în toate patru cazuri suportul pentru cuib este asigurat de specia Plopul negru (Populus nigra). După cum se știe păsările răpitoare sunt buni indicatori ai mediului, prezența acestea indică calitatea ecosistemelor și gradul de impact antropic. Acestea explică faptul că în preajma fluviului Nistru nu s-a identificat nici o pereche cuibăritoare, probabil că densitatea localităților din apropierea Nistrului este mare în comparație cu cea a zonei Prutului.

\section{Concluzii:}

1. Studiul de față acoperă toate sezoanele de cuibărit ale speciei 
(Haliaeetus albicilla) din 2012 până în prezent. Zonele studiate cuprind teritoriile din preajma lacurilor mari din țară și sectoarelor unde au fost observate frecvent exemplare din specia dată.

2. Numărul perechilor cuibăritoare a ajuns la patru, iar făcând comparație cu sfârșitul secolului trecut putem spune ca starea ecosistemelor din republică puțin s-a remediat.

3. Principala cauză a dispariției Codalbului este deranjul din perioada de cuibărit, lipsa hranei și defrișările masive de pădure care au loc în Republica Moldova.

Studiul a fost efectuat în cadrul proiectului fundamental 15.187.0211 F realizat la Institutul de Zoologie.

\section{Bibliografie:}

1. Atlasul Păsărilor Clocitoare din Republica Moldova, Chișinău 2010.

2. Cartea Roșie a Republicii Moldova, Ediția II Chișinău Știința 2001.

3. European Scietific Journal, WHITE-TAILED EAGLE (AVES: ACCIPITERIFORMES) STATUS IN REPUBLIC OF MOLDOVA May2014.

4. Аверин Ю. В., Ганю И. М. Успенский Г. А. Птицы Момдавии тю 2, Кищинев Щтиинца, 1971.

5. Зубков Н. Хищные птицы и совы Молдавии 1983. 